\title{
Chorea in systemic lupus erythematosus: association with antiphospholipid antibodies
}

\author{
M A KHAMASHTA, ${ }^{1}$ A GIL, ${ }^{1}$ B ANCIONES, ${ }^{2}$ P LAVILLA, \\ M E VALENCIA, ${ }^{1}$ V PINTADO, ${ }^{1}$ AND J J VÁZQUEZ
}

From the Departments of ${ }^{1}$ Internal Medicine and ${ }^{2}$ Neurology, Hospital 'La Paz', Universidad Autónoma, Madrid, Spain

SUMmaRY Chorea is a rare manifestation of systemic lupus erythematosus (SLE). In this report the clinical features of two cases of chorea associated with SLE are presented. Of special interest were the raised titres of antiphospholipid antibodies in both cases. The possible pathogenic role of these antibodies is briefly discussed.

Key words: focal cerebral ischaemia, lupus anticoagulant, anticardiolipin antibody, thrombosis, connective tissue disease.

Recent reports of large series of patients with systemic lupus erythematosus (SLE) suggest that neuropsychiatric manifestations are common, occurring in about $50 \%$ of affected patients. ${ }^{1-4}$ Chorea has been reported in less than $2 \%$ of all cases. Recently, Asherson et al reported 12 cases of chorea in SLE and related disorders. ${ }^{5}$ In nine of these patients antiphospholipid (aPL) serum antibodies were detected at some stage of their illness. These authors propose a direct link between these autoantibodies and the development of chorea. We here report an additional two patients fulfilling the revised criteria of the American Rheumatism Association for SLE, ${ }^{6}$ in whom chorea was the presenting feature of the disease. In both cases aPL antibodies were present.

\section{Case reports}

CASE 1

A 13 year old white girl was admitted to our hospital for the first time in November 1986 because of a one week history of choreiform movements involving all four extremities.

She was well until May 1984 when, at the age of 10 years, she developed polyarthralgia and a butterfly rash, followed six months later by gross involuntary movements of the extremities. She was admitted to another hospital where she received

Accepted for publication 1 February 1988.

Correspondence to Dr M A Khamashta, Lupus Research Laboratory, The Rayne Institute, St Thomas's Hospital, London SE1 7EH. treatment with methylprednisolone $(60 \mathrm{mg}$ daily), and a marked improvement in her neurological manifestations followed. Corticosteroid treatment was reduced to a maintenance level of $10 \mathrm{mg}$ on alternate days and discontinued one year later. She remained asymptomatic until one week before admission when abnormal movements recurred. She had not complained of sore throat in the year before entry. There was no family history of neurological or collagen disease.

On admission to hospital she was mentally slow, markedly irritable, febrile, had a slight butterfly facial rash, and was mildly hypertensive (blood pressure $160 / 100 \mathrm{mmHg}$ ), with livedo reticularis on the lower extremities. Examination showed her cardiorespiratory and gastrointestinal systems to be normal. Neurological examination showed bilateral choreiform movements of the extremities but no other neurological abnormalities.

Laboratory findings included a normochromic normocytic anaemia (haemoglobin $110 \mathrm{~g} / \mathrm{l}$ ), packed cell volume 29 , white blood cell count $6 \cdot 4 \times 10^{9} / 1$, with $69 \%$ polymorphs, $29 \%$ lymphocytes, and $2 \%$ eosinophils. Her platelet count was $184 \times 10^{9} / 1$ and erythrocyte sedimentation rate $76 \mathrm{~mm} / \mathrm{h}$. Renal function tests showed a blood urea of $13.4 \mathrm{mmol} / \mathrm{l}$, creatinine clearance of $122 \mathrm{ml} / \mathrm{min}$, and 24 hour urinary protein of $1 \cdot 3 \mathrm{~g}$.

Her antinuclear antibody titre was positive (1/2560) and the Crithidia luciliae test for antidsDNA was also positive. Latex test for rheumatoid factor and antibodies against extractable nuclear antigens were negative. A Coombs' test was positive, 
with hypocomplementaemia (C4 $55 \mathrm{mg} / \mathrm{l}$; normal range $200-600 \mathrm{mg} / \mathrm{l}$ ) and a biological false positive Venereal Disease Research Laboratory (VDRL) test. The lupus anticoagulant was present, and IgG anticardiolipin antibody was positive in low titre. Her electroencephalogram (EEG) showed only non-specific slowing, and computed tomographic (CT) brain scan was normal. Renal biopsy demonstrated membranous glomerulonephritis. Sydenham's chorea was ruled out on the basis of negative antistreptolysin $\mathrm{O}$ titres. The electrocardiogram, chest $x$ ray, and cardiac evaluations were all normal.

A diagnosis of SLE was made, and the patient was treated with high doses of steroids (methylprednisolone $60 \mathrm{mg}$ daily and cyclophosphamide $50 \mathrm{mg}$ daily). She responded well and showed a marked improvement in her mental state and choreiform movements within two weeks. At follow up 12 months later she remained asymptomatic while receiving low dose methylprednisolone $(16 \mathrm{mg}$ on alternate days). The IgG anticardiolipin antibody level fell to normal range, but the lupus anticoagulant activity remained unmodified.

\section{CASE 2}

A 22 year old white woman was first admitted to our hospital in May 1982 at the age of 17 years. She complained of polyarthralgia affecting the small joints of hands and elbows, a butterfly rash, fever, and the sudden onset of right sided chorea of the extremities and head. Her past medical history was not relevant. The diagnosis of SLE was established because of polyarthritis, skin manifestations, central nervous system involvement, leucopenia, thrombocytopenia $\left(60 \times 10^{9} / 1\right)$, a biological false positive VDRL test, low concentration of complement $(\mathrm{C} 460 \mathrm{~g} / \mathrm{l})$, positive tests for antinuclear antibodies $(1 / 640)$, dsDNA, anti-Sm antibodies, and a positive LE cell test. Normal investigations included chest $x$ ray, electrocardiogram, EEG, echocardiogram, brain CT scan, and an examination of the cerebral fluid. Antistreptolysin $\mathrm{O}$ titres were negative. Treatment was started with high doses of methylprednisolone $(60 \mathrm{mg}$ daily) and cyclophosphamide (50 mg daily), and the choreiform movements and other systemic symptoms were markedly diminished within one week. She was subsequently well until April 1987 when she had a first trimester spontaneous abortion. Two months later she developed polyarthralgia, cutaneous rash, depression, marked irritability, and occasional right sided choreiform movements. On admission she was markedly irritable, had a butterfly rash, but was normotensive. General, musculoskeletal, cardiovascular, and neurological examinations were all normal, apart from mild right sided hemichoreiform movements.
Laboratory findings were essentially similar to those on the previous admission. On this occasion $\overrightarrow{\vec{F}}$ high titres of IgM anticardiolipin antibodies were $\stackrel{0}{\rightarrow}$ found and the test for lupus anticoagulant was positive.

A good clinical and immunological response was $\frac{\overline{\bar{m}}}{\bar{\nabla}}$ achieved with immunosuppressive treatment $\stackrel{\Phi}{\varrho}$ (methylprednisolone $60 \mathrm{mg}$ daily and cyclophos- के phamide $50 \mathrm{mg}$ daily).

\section{Discussion}

Chorea is a well recognised but rare manifestation of SLE. ${ }^{5-9}$ In a recent review the authors found less than 100 reported cases. ${ }^{5} \mathrm{~A}$ retrospective study of $i$ central nervous system disease in 105 patients with SLE seen in our department during the past 15 years $\stackrel{\infty}{\rightarrow}$ revealed two patients with chorea, lupus anti- 을 coagulant, and anticardiolipin antibodies. Although $\rightarrow$ chorea usually occurs during the course of SLE, it may also be, as in these two cases, the presenting feature of the illness, sometimes preceding other $\stackrel{\text { of }}{\rightarrow}$ symptoms by several years. ${ }^{1(-1)}$ It has also been $\vec{\bullet}$ reported that chorea may appear after the adminis- $\infty$ tration of oral contraceptives, ${ }^{14}$ during pregnancy ('chorea gravidarum'), ${ }^{13} 15$ and rarely in the puerperium. ${ }^{16}$ Our second patient, who had an episode of chorea at the onset of her illness, had a recurrence of chorea five years later, two months $\frac{\circ}{\Phi}$ after a first trimester abortion. As in other reported cases $^{10} 1217$ there was a dramatic disappearance of chorea within a few days of starting immunosuppressive treatment.

Although the pathophysiology of chorea in SLE is unknown, ${ }^{10} 18$ an association with aPL antibodies has recently been suggested. ${ }^{58}$ Because anticardiolipin antibodies are known to cross react with other 3 . phospholipids $^{20}$ it has been suggested that direct $\delta$ antibody mediated damage to phospholipid contain- $\underset{3}{2}$ ing structures in the basal ganglia may play a part in 을 the pathogenesis of these disorders. ${ }^{5}$ Necropsy investigations have failed to show lesions in areas of $\frac{7}{2}$ the brain which one might expect to correlate with the clinical picture of chorea. ${ }^{\circ}$ On the other hand, $\sigma$ in view of the known thrombotic tendency of such $N$ patients $^{21}$ the observations that chorea may dis- N appear spontaneously and that it can occur on different sides in a single patient suggest that reversible ischaemia rather than infarction may be occurring. 522 The absence of any abnormality on $\stackrel{\Phi}{+}$ CT brain scans performed during episodes of chorea in our patients strongly supports this hypothesis, and ${ }_{0}$ a similar observation has been noted by Asherson $\stackrel{\mathbb{D}}{\mathbb{D}}$ et al. ${ }^{5}$ Recent studies performed on serum samples $\frac{\rho}{\mathbb{D}}$ of patients with chorea (R A Asherson, R Williams, $\frac{\circ}{\square}$ personal communication) have demonstrated anti- 
neuronal activity against cadaver basal ganglia preparations, suggesting an antigen-antibody mediated mechanism in the production of the chorea rather than vascular occlusion. There is a striking association in SLE between thrombotic complications and the presence of aPL antibodies. $^{21-2.3}$ Although the clinical association. is strong, the mechanism by which these antibodies cause thrombosis is not well established. Carreras and Vermylen suggest that these antibodies may bind phospholipids in endothelial cell membranes, ${ }^{2+}$ resulting in inhibition of arachidonic acid release, decreased prostacyclin formation, increased platelet aggregation, and thrombosis. It has also been suggested that aPL antibodies may play a more direct part in thrombosis by binding phospholipids in platelet membranes. ${ }^{25}$ We have recently demonstrated binding of these antibodies to freeze thawed but not to intact platelets. ${ }^{26}$ This suggests that if these antibodies do bind platelets, some perturbation of the platelet membrane must first occur in vivo. As the chorea in SLE frequently responds to drug treatment directed against the SLE we agree with Agrawal and Foa ${ }^{1.3}$ that chorea initially should not be treated with secondary agents, such as haloperidol. On the other hand, we agree with the recommendation of Hodges, ${ }^{7}$ that aPL antibodies should be looked for in all unexplained cases of chorea, even in patients with no other serological or clinical features of SLE.

\section{References}

1 Grigor R. Edmonds J. Lewkonia R. Hughes G R V. Systemic lupus erythematosus. Ann Rherum Dis 1978: 37: 122-8.

2 Gibson T. Myers A R. Nervous system involvement in systemic lupus erythematosus. Ann Rheum Dis 1976; 35: 398-406.

3 Feinglass E J. Arnett F C. Dorsch C A. Zizic T M. Stevens M B. Neuropsychiatric manifestations of systemic lupus erythematosus: diagnosis. clinical spectrum and relationship to other features of the discase. Medicine (Baltimore) 1976; 55: 323-39.

4 Anciones B. Hernández Pérez M A. Valencia E. Pintado V. Medraño J C. Manifestaciones neurológicas en el lupus eritematoso sistémico. In: Anciones B. ed. Vasculitis y sistema nervioso. Barcelona: MCR. 1987: 111-31.

5 Asherson R A. Derksen R H W M. Harris E N. et al. Chorea in systemic lupus erythematosus and 'lupus like' disease: association with antiphospholipid antibodies. Semin Arthritis Rheum 1987: 16: 253-9.
6 Tan E M. Cohen A S. Fries J F. et al. The 1982 revised criteria for the classification of systemic lupus erythematosus. Arthritis Rheum 1982; 25: 1271-7.

7 Hodges J R. Chorea and the lupus anticoagulant. J Neurol Neurosurg Psychiatry 1987; 50: 368-9.

8 Bouchez B. Arnott G, Hatron P Y. Choréc et lupus érythémateux disseminć avec anticoagulant circulant: trois cas. Rev Neurol (Paris) 1985; 141: 571-7.

9 Olsen J E. Chorea minor associated with systemic lupus crythematosus: report of a case. Acta Med Scand 1968: 183: 127-9.

10 Lusins J O. Szilagyi P A. Clinical features of chorea associated with systemic lupus crythematosus. Am J Med 1975; 58: 857-61.

11 Kukla L F. Reddy C. Silkalns G. Prasad M. Systemic lupus erythematosus presenting as chorea. Arch Dis Child 1978; 53: 345-7.

12 Arisaka O. Obinata K. Sasaki H. Arisaka M. Kancko K. Chorea as an initial manifestation of systemic lupus erythematosus. Clin Pediatr (Phila) 1984: 23: 298-300).

13 Agrawal B L. Foa R P. Collagen vascular discase appearing as chorea gravidarum. Arch Neurol 1982: 39: 192-3.

14 Asherson R A. Harris E N, Gharavi A E. Hughes G R V. Systemic lupus crythematosus, antiphospholipid antibodies. chorca and oral contraccptives. Arthritis Rheum 1987; 30: $1535-6$.

15 Lubbe W F, Walker E B. Chorea gravidarum associated with circulating lupus anticoagulant: successful outcome of pregnancy with prednisone and aspirin therapy. Case report. $B r J$ Obstet Gynaecol 1983; 90: 487-90.

16 Thomas D. Byrne P D. Travers R L. Systemic lupus erythematosus presenting as post-partum chorea. Aust NZ J Med 1979: 9: 568-70.

17 Hatron P Y. Bouchez B. Wattel A. Arnott G. Devulder B. Lille C H R. Chorea. systemic lupus erythematosus, circulating lupus anticoagulant. $J$ Rheumatol 1986: 13: 991-3.

18 Harris E N. Hughes G R V. Cerebral disease in systemic lupus crythematosus. Springer Semin Immunopathol 1985: 8: 251-6.

19 García Puig J. Gil Aguado A. Barbado J. García Seoane J. Vázquez J J. Manifestaciones ncuropsíquicas en el lupus critematoso sistémico. Med Clin (Barc) 1979; 72: 133-8.

20) Harris E N. Gharavi A E. Loizou S, et al. Crossreactivity of antiphospholipid antibodics. J Clin Lab lmmunol 1985: 16: 1-6.

21 Harris E N. Chan J K. Asherson R A. Aber V R. Gharavi A E. Hughes G R V. Thrombosis, recurrent fetal loss and thrombocytopenia: predictive value of the anticardiolipin antibody test. Arch Intern Med 1986: 146: 2153-6.

22 Bingley P J. Hoffbrand B I. Antiphospholipid antibody syndrome: a revicw. $J R$ Soc Med 1987: 80: 445-8.

23 Asherson R A. Harris E N. Anticardiolipin antibodics: clinical association. Postgrad Med J 1986: 62: 1081-7.

24 Carreras L O. Vermylen J G. Lupus anticoagulant and thrombosis: possible rolc of inhibition of prostacyclin formation. Thromb Haemost 1982: 48: 28-40.

25 Harris E N. Gharavi A E. Hughes G R V. Antiphospholipid antibodics. Clin Rheum Dis 1985: 11: 591-609.

26 Khamashta M A. Harris E N. Gharavi A E, et al. Do anticardiolipin antibodics cause thrombosis through a platelet mediated mechanism? Br J Rheumatol 1987; 26 : 94. 